\title{
Effect of replacing beef fat with safflower oil on physicochemical, nutritional and oxidative stability characteristics of wieners
}

\author{
Emel KAYNAKCI ${ }^{1 *} \mathbb{D}$, Birol KILIÇ²
}

\begin{abstract}
Five treatments of wieners were prepared with replacing 0, 25, 50, 75 and 100\% of added beef back fat with safflower oil (SO). Changes in $\mathrm{pH}$, thiobarbuturic acid reactive substances (TBARS) and color $\left(\mathrm{L}^{*}, \mathrm{a}^{*}, \mathrm{~b}^{*}\right)$ values of wieners were determined during manufacturing day and refrigerated storage $(5,10,15,20$ and $30 \mathrm{~d})$. Fatty acid profile, cholesterol content, cooking loss, proximate composition and textural properties of wieners were also determined on manufacturing day. Results revealed that SO incorporation in wiener formulation resulted in a higher unsaturated fatty acid contents $(\mathrm{P}<0.05)$. Wieners manufactured with a $50 \%$ or higher fat replacement with SO resulted in lower cholesterol content compared to other treatments $(\mathrm{P}<0.05)$. Increasing the amount of SO used for beef back fat replacement in wieners created higher TBARS formation during the storage period $(\mathrm{P}<0.05)$. Incorporation of $\mathrm{SO}$ increased CIE $\mathrm{L}^{*}$ and $\mathrm{b}^{*}$ values, whereas it caused a decrease in $\mathrm{CIE} \mathrm{a}^{*}$ values of wieners $(\mathrm{P}<0.05)$. On the other hand, replacing beef back fat with SO did not affect sensory attributes of wieners. Study results indicated that replacement rate of beef back fat with SO up to $50 \%$ can be good strategy for the meat industry to produce desirable and healthy weiners.
\end{abstract}

Keywords: plant oil; meat products; cholesterol; fatty acids.

Practical Application: Using safflower oil instead of beef fat in wieners.

\section{Introduction}

Wieners are emulsified meat products with 20-30\% animal fat content and have high consumption in many countries (Ospina-E et al., 2015). Wieners are usually manufactured with animal based fats such as beef and pork back fats (Henck et al., 2019; Novakovic et al., 2019). Animal fat plays a key role in many quality traits of meat products, including nutritional value and sensory properties, as well as the technological aspects (Gómez \& Lorenzo, 2013). Furthermore, it also has an important role in stabilizing emulsion, reducing cooking loss and improving juiciness and textural properties (Lorenzo et al., 2014). Hovewer, fat present in meat and meat products are mostly composed of saturated fatty acids (SFA) which have been associated with elevated blood cholesterol level and an increased risk of cancers, hypertension and obesity (Câmara \& Pollonio 2015). The high level of blood LDL-cholesterol has been reported to be one of the major causes for cardiovascular diseases (Reddy et al., 2015). In response, consumers are demanding from their food to be not only safe and nutritious, but also healthy and natural (Tahmasebi et al., 2016). These demands force manufacturers and researchers to develop healthier meat products (Lorenzo et al., 2016; Heck et al., 2017, 2019).

Most authorities such as the U.S. Department of Agriculture (USDA) and the World Health Organization (WHO) recommend intake of oils because of their polyunsaturated fatty acids (PUFA) such as linoleic and linolenic fatty acids which cannot be synthesized by human body (Reddy et al., 2015). Therefore, several vegetable oils have been utilized as an animal fat replacer in the production of various meat products for enrichment of the products with unsaturated fatty acids, improvement of unsaturated and saturated fatty acid ratio (Barros et al., 2020; Vargas-Ramella et al., 2020; de Carvalho et al., 2019; Ospina-E et al., 2015) and reducing cholesterol content (Delgado-Pando et al., 2010). Some vegetable oils such as n-3 PUFA enriched oil (López-López et al., 2009), canola oil (Selani et al., 2016), palm oil (Tan et al., 2006), fish oil (Marchetti et al., 2014), linseed oil (Carvalho et al., 2020; Franco et al., 2020), grapeseed oil (Choi at al., 2010), sesame oil (Zhuang et al., 2016), camellia oil (Wang et al., 2018), olive oil, sunflower oil and avocado oil (Rodríguez-Carpena et al., 2012) have been studied previously to replace animal fat in various meat products.

Safflower oil is obtained from Carthamus tinctorius L.. plant seeds that have a fat content of 35-37\% (La Bella et al., 2019). As far as the health benefits of safflower oil are concerned, safflower oil contains about $73.7 \%$ oleic acid (La Bella et al., 2019) and American Hearth Association (2016) reported that safflower oil is high in MUFA. The main components of safflower oil (SO) are linoleic acids (cis-9, cis-12 18:2) and cis-9, trans-11 conjugated linoleic acid (CLA). These unsaturated fatty acids such as cis-9, trans-11 CLA are potential antioxidant, antiatherogenic, hypolipidemic and anti-hypertensive (Ebadia et al., 2014). Therefore, incorporation of safflower oil in wiener formulation 
may improve the potential of the meat products to enhance consumer health benefits.

The aim of present study was to investigate the effect of safflower oil incorporation as a beef fat replacer on physicochemical, sensorial and shelf life characteristics of wieners.

\section{Materials and methods}

\subsection{Materials}

A $24 \mathrm{~h}$ post mortem fresh lean chicken breast meat (Musculus pectoralis) and beef fat were supplied from Gülköy Meat Integrated Plant (Isparta, Turkey). Before the production, the meat was ground with the grinder with $3 \mathrm{~mm}$ plate (Model PKM 22/32, Arı Makine, Istanbul, Turkey). $\mathrm{pH}$ of the meat used in our study ranged from 6.02 to 6.36. Safflower oil was obtained from Sungur Co. (Sivas, Turkey). Whey powder, sodium erithorbate, sodium chloride, sodium nitrite, liquid smoke and wiener spices mix were provided by Gülköy Meat Integrated Plant (Isparta, Turkey).

\subsection{Wiener manufacturing}

Wiener treatments are presented in Table 1. Wiener batter was prepared with ice, sodium nitrite, whey powder, beef fat, spices mix, and liquid smoke in a cutter (Cutter A-20, Ramon, Spain). Safflower oil was also incorporated into meat batter during this process according to formulation of each treatment. Wiener batter was stuffed into cellulose casing with $15 \mathrm{~mm}$ diameter by using a stuffer (Model SC-13, Ramon, Spain). Wiener batters were then subjected to cooking in smokehouse (Model FPK 100, Ar1 Makina, Turkey). The cooked wieners were then vacuum packaged in a polyethylene polyamide plastic bags and stored at $4^{\circ} \mathrm{C}$. TBARS, color and $\mathrm{pH}$ analysis were performed on manufacturing day and storage period $(5,10,15,20$, and $30 \mathrm{~d})$. Physicochemical analysis, cooking loss, cholesterol, fatty acid profile, texture and sensory analysis were also carried out once on processing day.

\subsection{Cooking loss and proximate composition}

Cooking loss of wieners were determined according to the method described by Kiliç et al. (2018). The moisture (Association of Official Analytical Chemists, 1997), ash (Association of Official Analytical Chemists, 2000), protein (Association of Official Analytical Chemists, 1997) and fat (Association of
Official Analytical Chemists, 1997) levels of wiener samples were determined according to the AOAC (Association of Official Analytical Chemists, 1997) method.

\subsection{Cholesterol determination}

Lipids of wiener samples were extracted, and the cholesterol content was determined according to the method described by Intarasirisawat et al. (2011). Lipids were methylated with tetramethylammonium hydroxide and subjected to gas chromatograhpy analysis. The analysis of cholesterol was conducted using an HP-Innowax capillary column $(10 \mathrm{~m} \times 0.10 \mathrm{~mm}$ I.D., Agilent Technologies Inc., Santa Clara, CA, USA) connected to a Agilent 7820A gas chromatography (Agilent Technologies, USA) with a flame ionization detector. High purity helium was used as the carrier gas set at $1.0 \mathrm{~mL} / \mathrm{min}$, and the sample $(1 \mu \mathrm{L})$ was injected into the GC. The temperature of the injector port was set at $275^{\circ} \mathrm{C}$. Split injection mode (10:1 for each injection) was used. Oven temperature was set at $250^{\circ} \mathrm{C}$ and held for $15 \mathrm{~min}$, and the detector temperature was set at $300^{\circ} \mathrm{C}$. The cholesterol standard (C8667-56, Sigma-Aldrich) was used for the GC analysis. The content of cholesterol for each sample was calculated from peak area and expressed as $\mathrm{mg} / 100 \mathrm{~g}$.

\subsection{Measurement of fatty acid profile}

Lipids were extracted from wieners according to Folch et al. (1957). Following the extraction of lipids, analysis of fatty acid profile was performed with gas chromotography (7820A, Agilent Technologies, USA) equipped with an electron impact (EI) ionisation detector. A column, Cp WAX 52 CB $50 \mathrm{~m}^{\star} 0,32 \mathrm{~mm}$, $1,2 \mu \mathrm{m}$ was used. The operating conditions were as follows: column temperature, $240^{\circ} \mathrm{C}$; injector temperature, $250^{\circ} \mathrm{C}$; detector temperature, $250^{\circ} \mathrm{C}$. The carrier gas used was helium, at a flow pressure of $10 \mathrm{psi}$. The column was operated at $60^{\circ} \mathrm{C}$ for $4 \mathrm{~min}$, then the temperature was increased gradualy to $240^{\circ} \mathrm{C}$ at a rate of $4{ }^{\circ} \mathrm{C} / \mathrm{min}$. Fatty acids were identified by comparison of their retention time with appropriate standards (Supelco 18919-1AMP, Sigma-Aldrich). The results were expressed in weight percent of the total amount of fatty acids (Khoddami et al., 2009).

\subsection{Texture profile analysis}

Texture profile analysis was performed using a TA.XT2 Texture Analyzer (Texture Technologies Corp., Scarsdale, NY/Stable Micro Systems, Godalming, UK) as described by

Table 1. Formulations of wiener treatments.

\begin{tabular}{|c|c|c|c|c|c|}
\hline \multirow{2}{*}{ Ingredients (\%) } & \multicolumn{5}{|c|}{ Treatments } \\
\hline & Control & $25 \mathrm{SO}$ & $50 \mathrm{SO}$ & $75 \mathrm{SO}$ & $100 \mathrm{SO}$ \\
\hline Ground meat & 69.2 & 69.2 & 69.2 & 69.2 & 69.2 \\
\hline Ice & 13.84 & 13.84 & 13.84 & 13.84 & 13.84 \\
\hline Beef fat & 13.84 & 10.38 & 6.92 & 3.46 & - \\
\hline Safflower oil & - & 3.46 & 6.92 & 10.38 & 13.84 \\
\hline Whey powder & 0.69 & 0.69 & 0.69 & 0.69 & 0.69 \\
\hline Spice mix & 1.04 & 1.04 & 1.04 & 1.04 & 1.04 \\
\hline Curing salt & 1.38 & 1.38 & 1.38 & 1.38 & 1.38 \\
\hline Liquid smoke & 0.003 & 0.003 & 0.003 & 0.003 & 0.003 \\
\hline
\end{tabular}

Control: $100 \%$ beef fat; 25 SO: $25 \%$ safflower oil + 75\% beef fat; 50 SO: $50 \%$ safflower oil $+50 \%$ beef fat; 75 SO: $75 \%$ safflower oil $+25 \%$ beef fat; 100 SO: $100 \%$ safflower oil. 
Kilıç et al. (2018). Before the analysis, wiener samples were stored at room temperature for $30 \mathrm{~min}$ to provide homogeneity and cut into $2-\mathrm{cm}$ thick sections. The analysis was performed using a $5 \mathrm{~mm}$ cylindrical stainless steel plunger attached to a $50 \mathrm{~N}$ cell connected to the crosshead (crosshead speed of $50 \mathrm{~mm} / \mathrm{min}$ ) and compressed by $70 \%$. Analysis of force-times curves led to the identification of measured textural parameters. Measurements were taken in ten replicates from different locations of samples and hardness values were calculated by the software program. Hardness was the maximum peak force during compression.

\section{$2.7 \mathrm{pH}$ analysis}

The $\mathrm{pH}$ measurements were taken with spear tip electrode (Hanna Instruments HI 9024, Italy) on homogenates of $10 \mathrm{~g}$ of wiener sample and $90 \mathrm{ml}$ of distilled water (Chouliara et al., 2007).

\subsection{Color analysis}

CIE Color values $\left(L, a^{*}, b^{*}\right)$ of wiener batter and wiener samples were measured by a Minolta Chroma Meter CR-200, Minolta Camera Co., Japan (Luo, 2006). The colorimeter was calibrated using a standard white ceramic plate. The color measurements were replicated ten times using different parts of wiener samples.

\subsection{Thiobarbituric acid reactive substances (TBARS) analysis}

TBARS were determined using the muscle extraction procedure of Lemon (1975) with some modifications (Kilic \& Richards 2003). This method requires addition of EDTA and propyl gallate to the trichloroacetic acid (TCA) extraction solution to prevent the development of TBARS during the analytic procedure. The TBARS values were expressed as $\mu \mathrm{mol}$ TBARS per $\mathrm{kg}$ of sample. A standard curve was prepared using 1,1,3,3-tetraethoxypropane.

\subsection{Sensory analysis}

The degree of difference and descriptive sensory analysis were performed at the Department of Food Sciences at the Suleyman Demirel University. Sensory analysis was performed by a total of 25 panelists ( 13 males and 12 females), who were between 17 and 25 years old, non-smoker, and experienced in the sensory evaluation of foods. The procedures described in the IFT
Guideline (Institute of Food Technologists, 1981) were applied in sensory analysis. Sensorial attributes of wieners samples were evaluated for color, odor, flavor, taste, juiciness, texture and the overall acceptability. Samples were sliced to $1 \mathrm{~cm}$ thickness and chosen randomly from each treatment. Wieners were served hot (approximately $50^{\circ} \mathrm{C}$ ) after heated $40 \mathrm{~s}$ at microwave oven.

\subsection{Statistical analysis}

The entire experiment was replicated three times on separate production days. Data collected for chemical composition, physicochemical properties and sensory attributes were analyzed. Statistical analysis was performed using SPSS 17.0 (Version 17.0. Chicago, IL, USA). The generated data were analyzed by analysis of variance (ANOVA). Differences among mean values were established using the Tukey multiple range test and were considered significant when $\mathrm{P}<0.05 . \mathrm{pH}$, TBARS, color $\left(\mathrm{L}^{*}, \mathrm{a}^{*}, \mathrm{~b}^{*}\right)$ data were also analyzed by Repeated Measures (GLM). Significance level of $\mathrm{P} \leq 0.05$ was used for all evaluations.

\section{Results and discussion}

\subsection{Cooking loss, proximate composition and textural properties}

Cooking loss values of wieners are shown in Table 2. Cooking loss values of all wiener treatments varied between $6.06-7.69 \%$. There was no difference among treatments in terms of cooking loss $(\mathrm{P}>0.05)$. Jiménez-Colmenero et al. (2010) reported that replacement of pork backfat by oil-in-water emulsion had no effect on cooking loss of frankfurters. Ospina-E et al. (2015) also stated that there was no difference between the cooking losses of the frankfurters produced by replacing the animal fat with the chemicaly modified vegetable oils.

Moisture, ash, protein, fat and hardness values are presented in Table 2. There were no significant differences in ash, protein and hardness values among wiener treatments. Protein levels of the wiener samples produced in this study ranged from $12.53 \%$ to $13.52 \%$. Similar protein values were reported for chicken frankfurters (Ospina-E et al., 2015). Results revealed that moisture content significantly decreased when the increasing the safflower oil incorporation rate in the wiener formulation $(\mathrm{P}<0.05)$. Yllmaz et al., (2002) reported similar results for frankfurters made with the sunflower oil. According to Turkish Sausage Standards (Turkish Standards Institute, 2016), the moisture value of sausages should not exceed $65 \%$. In this regard, the moisture values of all wiener treatments were in accordance with

Table 2. Physico-chemical composition ${ }^{\star}$ of wiener treatments.

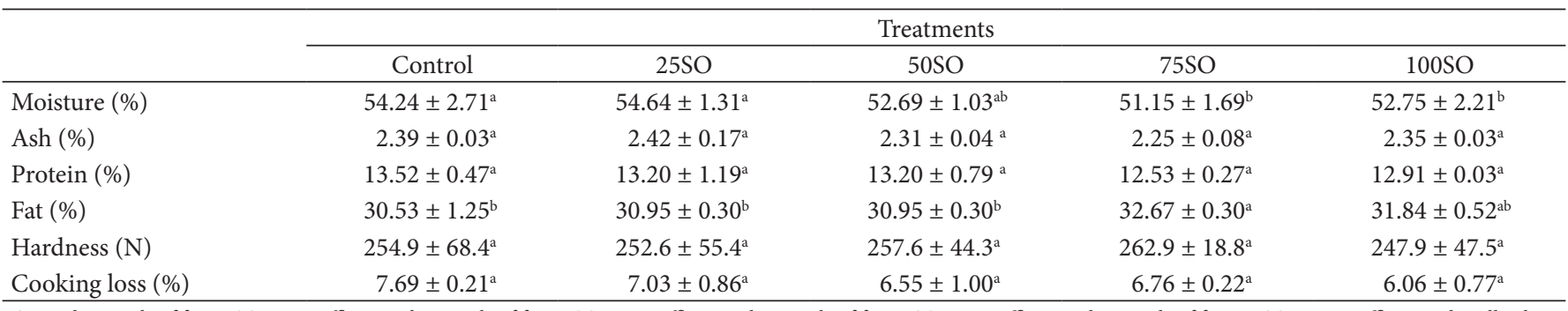

Control: $100 \%$ beef fat; 25 SO: $25 \%$ safflower oil + 75\% beef fat; 50 SO: $50 \%$ safflower oil + 50\% beef fat; 75 SO: $75 \%$ safflower oil + $25 \%$ beef fat; 100 SO: $100 \%$ safflower oil; ${ }^{\star}$ All values are the mean \pm standard error of three replicates; $\mathrm{a}, \mathrm{b}(\rightarrow)$ Different letters within a row are significantly different $(\mathrm{p}<0.05)$. 
TS 980 Turkish Sausage Standards. Previous studies indicated that adding vegetable oils causes softening problem in meat products (Yıldız-Turp \& Serdaroğlu, 2008). The present study results revealed that addition of safflower oil did not cause any change in hardness values of wieners.

Replacement of animal fats with vegetable oils was expected to increase the amount of total fat in the final product (Rodríguez-Carpena et al., 2012). Our study results also indicated that increasing the ratio of safflower oil in wiener formulation to replace beef fat resulted in an increased amount of total fat level in the final product $(\mathrm{P}<0.05)$.

\subsection{Cholesterol content and fatty acid profile}

The fatty acid composition of wieners are shown in Table 3. There were significant differences among treatments for cholesterol content $(\mathrm{P}<0.05)$. However, there was no difference between the control and $25 \mathrm{SO}$ treatment regarding cholesterol level. $2.00,18.64,22.92,23.70 \%$ reduction in cholesterol content were obtained in $25 \mathrm{SO}, 50 \mathrm{SO}, 75 \mathrm{SO}$ and $100 \mathrm{SO}$, respectively, compared to control $(\mathrm{P}<0.05)$. Muguerza et al., (2002) found that the cholesterol value of sausage produced by replacing $25 \%$ added animal fat with soybean oil was $5.98 \%$ lower than control. Another study showed that replacement of animal fat with vegetable oil caused cholesterol reduction in emulsion-type pork sausages (Lee et al., 2015).

The fatty acid composition has a great impact on the nutritional value, oxidative stability and sensory properties of muscle foods (Rodríguez-Carpena et al., 2012). In the present study, the most abundant fatty acids in control wiener samples were SFA, followed by MUFA and PUFA (Table 3). As compared with control, safflower replaced wieners had higher PUFA and MUFA levels. Addition of safflower oil also reduced myrictic, palmitic and stearic acids $(\mathrm{P}<0.05)$. It is well demonstrated that while stearic acis is neutral, palmitic and myristic acids produce the greatest atherogenic effect (Delgado-Pando et al., 2010). In our study palmitic and myristic acid decrased from 24.9 and $3.19 \%$ to 16.84 and $0.75 \%$, respectively when the beef fat was replaced by safflower oil. Results indicated that PUFA levels gradually increased with increasing the amount of added safflower oil $(\mathrm{P}<0.05)$. PUFA contents in 25SO, 50SO, $75 \mathrm{SO}$ and $100 \mathrm{SO}$ treatments increased $30.8,35.2,41.8$ and $44.72 \%$ respectively compare to control.

Asuming-Bediako et al. (2014) reported that replacing the pork backfat emulsion with rapeseed emulsion created an increase in MUFA and PUFA compositions from $45 \%$ to $59 \%$ and from $15 \%$ to $25 \%$ in sausage, respectively. From the nutritional point of view, PUFA/SFA ratio is one of the most important parameters and this ratio should be above 0.4 (Kasprzyk et al., 2015). The importance of the PUFA/SFA ratio in diets with reduced cholesterol level has been demonstrated by Marangoni et al., (2020). Research has been continuously undertaken to increase this ratio in the meat products (Paglarini et al., 2018, 2019, 2020). In this regard, the results showed that wieners manufactured in this study may be a good source for consumers with hyperlipidaemia, high cholesterol and heart diseases since PUFA/SFA ratios of wieners produced with SO were higher than 0.4 (Table 3).

\section{$3.3 \mathrm{pH}$, color and TBARS}

Effect of safflower incorporation on $\mathrm{pH}$, TBARS, color $\left(\mathrm{L}^{*}, \mathrm{a}^{*}\right.$ and $\left.\mathrm{b}^{*}\right)$ values of wieners stored at $4{ }^{\circ} \mathrm{C}$ during 30 days of storage are presented in Table 4 . There was difference in

Table 3. Fatty acid profile and cholesterol content of wieners

\begin{tabular}{|c|c|c|c|c|c|}
\hline Fatty acid & Control & $25 \mathrm{SO}$ & $50 \mathrm{SO}$ & $75 \mathrm{SO}$ & $100 \mathrm{SO}$ \\
\hline C10:0 & $0.045 \pm 0.06$ & - & - & - & - \\
\hline C12:0 & $0.09 \pm 0.09$ & - & $1.39 \pm 0.00$ & - & $1.36 \pm 0.01$ \\
\hline C14:0 & $3.19 \pm 2.13$ & $1.28 \pm 0.01$ & $1.26 \pm 0.49$ & $0.33 \pm 0.18$ & $0.75 \pm 0.07$ \\
\hline C16:0 & $24.9 \pm 2.11$ & $22.38 \pm 2.14$ & $20.68 \pm 1.94$ & $21.56 \pm 6.14$ & $16.84 \pm 2.39$ \\
\hline C17:0 & $0.66 \pm 0.00$ & $0.30 \pm 0.28$ & $0.28 \pm 0.00$ & - & $0.39 \pm 0.54$ \\
\hline $18: 0$ & $11.52 \pm 5.86$ & $14.41 \pm 2.16$ & $11.00 \pm 1.06$ & $7.93 \pm 1.53$ & $6.33 \pm 0.95$ \\
\hline$\Sigma \mathrm{SFA}^{\mathrm{A}}$ & 40.41 & 38.38 & 33.82 & 29.92 & 25.7 \\
\hline C16:1 & $3.46 \pm 2.23$ & $1.92 \pm 0.28$ & $1.69 \pm 0.01$ & $0.99 \pm 0.69$ & $1.42 \pm 0.14$ \\
\hline C18:1 & $29.65 \pm 3.01$ & $27.18 \pm 0.22$ & $26.83 \pm 0.99$ & $25.91 \pm 2.26$ & $26.44 \pm 0.80$ \\
\hline C18:1 (n-7) & $3.32 \pm 1.67$ & $1.05 \pm 1.27$ & $1.78 \pm 0.01$ & $1.03 \pm 0.90$ & $1.43 \pm 0.25$ \\
\hline$\sum \mathrm{MUFA}^{\mathrm{B}}$ & 36.43 & 30.15 & 30.03 & 27.93 & 29.29 \\
\hline $\mathrm{C} 18: 2(n-6)$ & $17.65 \pm 7.92$ & $28.81 \pm 1.47$ & $33.09 \pm 2.89$ & $40.59 \pm 0.13$ & $42.88 \pm 4.14$ \\
\hline a-Linolenic C18:3 (n_3) & $3.06 \pm 1.19$ & $1.89 \pm 0.54$ & $2.29 \pm 0.16$ & $1.28 \pm 1.03$ & $1.84 \pm 0.27$ \\
\hline$\sum \mathrm{n}-3$ & $3.06 \pm 1.19$ & $1.89 \pm 0.54$ & $2.29 \pm 0.16$ & $1.28 \pm 1.03$ & $1.84 \pm 0.27$ \\
\hline$\sum \mathrm{n}-6$ & $20.71 \pm 1.24$ & $28.96 \pm 1.62$ & $33.09 \pm 2.89$ & $40.59 \pm 0.13$ & $42.88 \pm 4.14$ \\
\hline$\Sigma \mathrm{PUFA}^{\mathrm{C}}$ & 23.77 & 30.85 & 35.29 & 41.87 & 44.72 \\
\hline PUFA/SFA & 0.59 & 0.8 & 1.04 & 1.4 & 1.74 \\
\hline MUFA+PUFA/SFA & 1.49 & 1.58 & 1.93 & 2.33 & 2.88 \\
\hline$n-6 / n-3$ & 6.76 & 15.32 & 14.45 & 31.71 & 23.3 \\
\hline Cholesterol mg/100 g & $43.20 \pm 2.18^{\mathrm{a}}$ & $42.39 \pm 2.68^{\mathrm{a}}$ & $35.15 \pm 1.45^{\mathrm{b}}$ & $33.30 \pm 1.92^{\mathrm{b}}$ & $32.96 \pm 2.47^{\mathrm{b}}$ \\
\hline
\end{tabular}

All values are the mean \pm standard error; $\mathrm{a}, \mathrm{b}(\rightarrow)$ Different letters within a row are significantly different $(\mathrm{p}<0.05)$; ${ }^{\mathrm{A}}$ Saturated fatty acids $\left(\right.$ SFA); ${ }^{\mathrm{B}}$ Monosaturated fatty acids $(\mathrm{MUFA})$; ${ }^{\mathrm{c}}$ Polyunsaturated fatty acids (PUFA). 
Table 4. $\mathrm{pH}$, TBARS and color $\left(\mathrm{CIE} \mathrm{L}^{*}, \mathrm{a}^{\star}, \mathrm{b}^{*}\right)$ results of wieners during storage at $4{ }^{\circ} \mathrm{C}$.

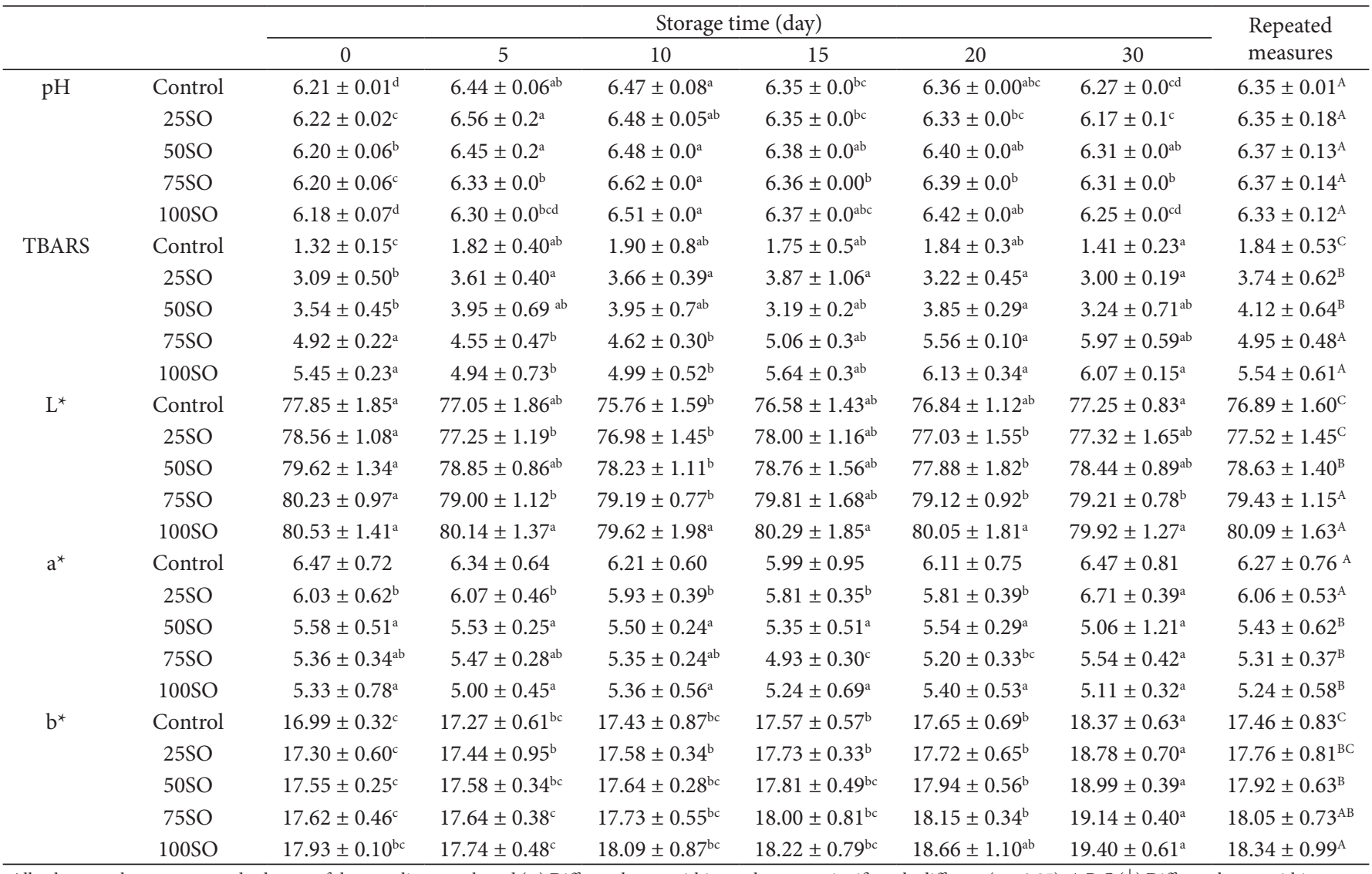

All values are the mean \pm standard error of three replicates; a, b, c, d $\rightarrow$ ) Different letters within a column are significantly different $(\mathrm{p}<0.05)$; A,B,C $(\downarrow)$ Different letters within a row are significantly different (the last column) $(\mathrm{p}<0.05)$.

the $\mathrm{pH}$ values of wieners during the storage days $(\mathrm{P}<0.05)$. Ospina-E et al. (2015) reported that there were no significant differences in $\mathrm{pH}$ values of frankfurter during storage time. In contrast, Pereira et al. (2020) reported that adding vegetable oil decreased the $\mathrm{pH}$ values in frankfurters. Sisik et al. (2012) have also observed a reduction in $\mathrm{pH}$ values during the cold storage in bologna type sausages.

TBARS values of wieners manufactured in this study ranged from 1.32-5.45 $\mu \mathrm{mol}$ TBARS per $\mathrm{kg}$ on manufacturing day. In general, lipid oxidation in all wiener samples increased during the storage $(\mathrm{P}<0.05)$. Pereira et al., $(2020)$ determined that there was a general increase in TBARS values during storage time in fat-reduced frankfurters. Based on the results of repeated measurements in the present study, it was found that TBARS values of $100 \mathrm{SO}$ and $75 \mathrm{SO}$ treatmens were higher than those of 25SO, $50 \mathrm{SO}$ and control $(\mathrm{P}<0.01)$. There were no significant differences among TBARS values of control, $25 \mathrm{SO}$ and $50 \mathrm{SO}$ treatmens $(\mathrm{P}<0.05)$. It was previously suggested that the extracts of safflower are potent radical scavengers and primary chain-breaking antioxidants (Ebadia et al., 2014).

Substitution of safflower oil had significant effects on the color parameters of wieners $(\mathrm{P}<0.01)$. The presence of safflower oil caused an increase in $\mathrm{L}^{*}$ and $\mathrm{b}^{*}$ values, in contrast, the presence of safflower oil reduced $\mathrm{a}^{*}$ values of the wiener samples compared to control. High $\mathrm{b}^{\star}$ values obtained in this study was thougt to be associated with color of added safflower oil. It was also previously reported that addition of vegetable oils (without interesterification) caused a decrease in $\mathrm{L}^{*}$ and $\mathrm{a}^{*}$ values and an increase in $b^{*}$ values of meat products (Ospina-E et al., 2015). Özvural \& Vural (2008) also found that the addition of interesterified vegetable oil and oil blends increased the $\mathrm{L}^{*}$ and $b *$ values of frankfurters. On the other hand, Vural (2003) stated that animal fat replacement with ineresterified oils has no effect on $L^{*}$ color values. Sisik et al., (2012) reported that presence of corn oil caused an increase in $L^{\star}$ values of Bologna type sausages. In another study, there was no change in $\mathrm{L}^{*}$ or $\mathrm{b}^{*}$ of the sausages manufactured with corn oil; meanwhile, $\mathrm{a}^{*}$ values were reported to be increased during $30 \mathrm{~d}$ storage and remained stable until day 45 , indicating that the products became redder during storage (Menegas et al., 2013).

\subsection{Sensory analysis}

Variance analyses for wieners are shown in Table 5. Results indicated that addition of safflower oil did not affect color, odor, flavor, taste, juiciness, texture and the overall acceptability of wieners compared to control. Zlatko et al. (2009) reported that chicken frankfurters made with plant oils are acceptable in terms of sensorial features. Yıldız-Turp \& Serdaroğlu (2008) 
Table 5. Sensory evaluation results of wieners.

\begin{tabular}{|c|c|c|c|c|c|c|}
\hline Treatments & Color & Color Intensity & Integrity & Hardness & Fragmentation & Juiciness \\
\hline Control & $5.69 \pm 2.39^{a}$ & $6.07 \pm 2.40^{\mathrm{a}}$ & $7.54 \pm 1.76^{\mathrm{a}}$ & $4.69 \pm 1.89^{a}$ & $5.15 \pm 2.61^{\mathrm{a}}$ & $5.31 \pm 1.65^{\mathrm{a}}$ \\
\hline $25 \mathrm{SO}$ & $6.62 \pm 1.98^{\mathrm{a}}$ & $5.00 \pm 2.23^{\mathrm{a}}$ & $7.54 \pm 2.18^{\mathrm{a}}$ & $5.31 \pm 1.84^{\mathrm{a}}$ & $5.00 \pm 2.16^{\mathrm{a}}$ & $4.69 \pm 1.44^{\mathrm{a}}$ \\
\hline $50 \mathrm{SO}$ & $6.69 \pm 1.97^{\mathrm{a}}$ & $4.15 \pm 2.51^{\mathrm{a}}$ & $7.08 \pm 2.43^{\mathrm{a}}$ & $5.31 \pm 1.37^{\mathrm{a}}$ & $5.85 \pm 2.19^{\mathrm{a}}$ & $5.31 \pm 1.38^{\mathrm{a}}$ \\
\hline $75 \mathrm{SO}$ & $6.54 \pm 1.81^{\mathrm{a}}$ & $4.38 \pm 2.87^{\mathrm{a}}$ & $7.77 \pm 1.79^{\mathrm{a}}$ & $5.08 \pm 1.32^{\mathrm{a}}$ & $5.31 \pm 2.02^{\mathrm{a}}$ & $5.54 \pm 1.45^{\mathrm{a}}$ \\
\hline \multirow[t]{2}{*}{$100 \mathrm{SO}$} & $6.38 \pm 2.40^{\mathrm{a}}$ & $3.77 \pm 2.98^{\mathrm{a}}$ & $7.31 \pm 1.93^{\mathrm{a}}$ & $5.08 \pm 1.71^{\mathrm{a}}$ & $5.31 \pm 1.89^{\mathrm{a}}$ & $5.00 \pm 1.58^{\mathrm{a}}$ \\
\hline & Oiliness & Flavor & Off-Flavor & Flavor Intensity & Odor & $\begin{array}{c}\text { Overall } \\
\text { Acceptability }\end{array}$ \\
\hline Control & $4.85 \pm 2.44^{\mathrm{a}}$ & $5.69 \pm 1.93^{\mathrm{a}}$ & $2.31 \pm 3.09^{\mathrm{a}}$ & $5.23 \pm 1.96^{\mathrm{a}}$ & $6.84 \pm 1.62^{\mathrm{a}}$ & $7.62 \pm 1.80^{\mathrm{a}}$ \\
\hline $25 \mathrm{SO}$ & $4.31 \pm 1.75^{\mathrm{a}}$ & $6.46 \pm 1.94^{\mathrm{a}}$ & $1.38 \pm 1.98^{\mathrm{a}}$ & $5.46 \pm 2.37^{\mathrm{a}}$ & $6.15 \pm 2.44^{\mathrm{a}}$ & $7.77 \pm 1.48^{\mathrm{a}}$ \\
\hline $50 \mathrm{SO}$ & $4.62 \pm 1.26^{\mathrm{a}}$ & $6.15 \pm 2.07^{\mathrm{a}}$ & $1.46 \pm 1.51^{\mathrm{a}}$ & $5.31 \pm 1.93^{\mathrm{a}}$ & $6.08 \pm 2.29^{\mathrm{a}}$ & $8.00 \pm 1.53^{\mathrm{a}}$ \\
\hline $75 \mathrm{SO}$ & $4.38 \pm 1.19^{\mathrm{a}}$ & $6.38 \pm 2.43^{\mathrm{a}}$ & $1.54 \pm 1.98^{\mathrm{a}}$ & $5.23 \pm 2.08^{\mathrm{a}}$ & $7.00 \pm 1.47^{\mathrm{a}}$ & $7.30 \pm 1.65^{\mathrm{a}}$ \\
\hline $100 \mathrm{SO}$ & $3.85 \pm 1.63^{\mathrm{a}}$ & $6.08 \pm 2.60^{\mathrm{a}}$ & $1.77 \pm 1.64^{\mathrm{a}}$ & $5.08 \pm 2.72^{\mathrm{a}}$ & $6.69 \pm 1.80^{\mathrm{a}}$ & $7.15 \pm 1.95^{\mathrm{a}}$ \\
\hline
\end{tabular}

All values are the mean \pm standard error of three replicates; a $\rightarrow$ ) Different letters within a column are significantly different $(\mathrm{p}<0.05)$.

indicated that sausages produced with $15 \%$ emulsified nut oil received the highest taste and the overall acceptability scores compared to sausages produced with animal fat. On the other hand, Pappa et al. (2000) have reported that using vegetable oil in meat products is not a suitable strategy because of undesirable color formation.

\section{Conclusion}

The results of the present study suggested that use of safflower oil instead of animal fat may be good strategy to improve fatty acid profile and reduce cholesterol content of wieners without any negative effect on chemical composition and sensory properties. It is also suggested that the replacement rate up to $50 \%$ can be good strategy for the meat industry to avoid possible shelf life problems in weiner processing.

\section{Acknowledgements}

Appreciation is expressed to Süleyman Demirel University, Department of Scientific Research Project (BAP) for providing financial support for this work (Project no: 1862-D-09).

\section{References}

American Hearth Association - AHA. (2016). A statement for healthcare Professionals from the nutrition Committee of Americans Hearth Association. Monosaturated fats. Chicago: AHA.

Association of Official Analytical Chemists - AOAC. (1997). Official methods of analysis of the Association of Official Analytical Chemists (16th ed., Sec. 39). Arlington: AOAC.

Association of Official Analytical Chemists - AOAC. (2000). Official methods of analysis of the Association of Official Analytical Chemists. Arlington: AOAC.

Asuming-Bediako, N., Jaspal, M. H., Hallett, K., Bayntun, J., Baker, A., \& Sheard, P. R. (2014). Effects of replacing pork backfat with emulsified vegetable oil on fatty acid composition and quality of UK-style sausages. Meat Science, 96(1), 187-194. http://dx.doi. org/10.1016/j.meatsci.2013.06.031. PMid:23906753.

Barros, J. C., Munekata, P. E. S., Carvalho, F. A. L., Pateiro, M., Barba, F. J., Domínguez, R., Trindadei, M. A., \& Lorenzo, J. M. (2020). Use of tiger nut (Cyperus esculentus L.) oil emulsion as animal fat replacement in beef burgers. Foods, 9(1), 44. http://dx.doi.org/10.3390/ foods9010044. PMid:31947797.

Câmara, A., \& Pollonio, M. (2015). Reducing animal fat in bologna sausage using pre-emulsified linseed oil: technological and sensory properties. Journal of Food Quality, 3(3), 201-212. http://dx.doi. org/10.1111/jfq.12136.

Carvalho, F. A. L., Lorenzo, J. M., Pateiro, M., Bermúdez, R., Purriños, L., \& Trindade, M. A. (2019). Effect of guarana (Paullinia cupana) seed and pitanga (Eugenia uniflora L.) leaf extracts on lamb burgers with fat replacement by chia oil emulsion during shelf life storage at 2 C. Food Research International, 125, 108554. http://dx.doi. org/10.1016/j.foodres.2019.108554. PMid:31554074.

Carvalho, F. A. L., Munekata, P. E., Pateiro, M., Campagnol, P. C., Domínguez, R., Trindade, M. A., \& Lorenzo, J. M. (2020). Effect of replacing backfat with vegetable oils during the shelf-life of cooked lamb sausages. Lebensmittel-Wissenschaft + Technologie, 122, 109052. http://dx.doi.org/10.1016/j.lwt.2020.109052.

Choi, Y. S., Choi, J. H., Han, D. J., Kim, H. Y., Lee, M. A., Kim, H. W., Lee, J. W., Chung, H. J., \& Kim, C. J. (2010). Optimization of replacing pork back fat with grape seed oil and rice bran fiber for reduced-fat meat emulsion systems. Meat Science, 84(1), 212-218. http://dx.doi.org/10.1016/j.meatsci.2009.08.048. PMid:20374777.

Chouliara, E., Karatapanis, A., Savvaidis, I. N., \& Kontominas, M. G. (2007). Combined effect of oregano essential oil and modified atmosphere packaging on shelf-life extension of fresh chicken breast meat, stored at $4{ }^{\circ} \mathrm{C}$. Food Microbiology, 24(6), 607-617. http://dx.doi. org/10.1016/j.fm.2006.12.005. PMid:17418312.

Delgado-Pando, G., Cofrades, S., Ruiz-Capillas, C., \& Jiménez-Colmenero, F. (2010). Healthier lipid combination as functional ingredient influencing sensory and technological properties of low-fat frankfurters. European Journal of Lipid Science and Technology, 112, 859-870.

Ebadia, F., Mohsenia, M., \& Alizadeh, A. M. (2014). Evaluation of antioxidant activity of Safflower florets (Carthamus tinctorius L.) as food coloring agents. Journal of Chemical and Pharmaceutical Research, 6(8), 539-544.

Folch, J., Lees, M., \& Sloane-Stanley, G. H. (1957). A simple method for the isolation and purification of total lipids from animal tissues. The Journal of Biological Chemistry, 226(1), 497-509. PMid:13428781.

Franco, D., Martins, A. J., López-Pedrouso, M., Cerqueira, M. A., Purriños, L., Pastrana, L. M., Vicente, A. A., Zapata, C., \& Lorenzo, J. M. (2020). Evaluation of linseed oil oleogels to partially replace pork backfat in fermented sausages. Journal of the Science of Food and 
Agriculture, 100(1), 218-224. http://dx.doi.org/10.1002/jsfa.10025. PMid:31512242.

Gómez, M., \& Lorenzo, J. M. (2013). Effect of fat level on physicochemical, volatile compounds and sensory characteristics of dry-ripened "chorizo" from Celta pig breed. Meat Science, 95(3), 658-666. http:// dx.doi.org/10.1016/j.meatsci.2013.06.005. PMid:23811106.

Heck, R. T., Saldaña, E., Lorenzo, J. M., Correa, L. P., Fagundes, M. B., Cichoski, A. J., de Menezes, C. R., Wagner, R., \& Campagnol, P. C. B. (2019). Hydrogelled emulsion from chia and linseed oils: a promising strategy to produce low-fat burgers with a healthier lipid profile. Meat Science, 156, 174-182. http://dx.doi.org/10.1016/j. meatsci.2019.05.034. PMid:31200329.

Heck, R. T., Vendruscolo, R. G., Etchepare, M. A., Cichoski, A. J., Menezes, C. R., Barin, J. S., Lorenzo, J. M., Wagner, R., \& Campagnol, P. C. B. (2017). Is it possible to produce a low-fat burger with a healthy $n-6 /$ n- 3 PUFA ratio without affecting the technological and sensory properties? Meat Science, 130, 16-25. http://dx.doi.org/10.1016/j. meatsci.2017.03.010. PMid:28347883.

Henck, J. M., Bis-Souza, C. V., Pollonio, M. A., Lorenzo, J. M., \& Barretto, A. C. (2019). Alpha-cyclodextrin as a new functional ingredient in low-fat chicken frankfurter. British Poultry Science, 60(6), 716-723. http://dx.doi.org/10.1080/00071668.2019.1664726. PMid:31532242.

Institute of Food Technologists - IFT. (1981). Sensory evaluation guide for the testing of food and beverage products. Sensory evaluation division. Food Technology, 35(11), 50-59.

Intarasirisawat, R., Benjakul, S., \& Visessanguan, W. (2011). Chemical compositions of the roes from skipjack, tongol and bonito. Food Chemistry, 124(4), 1328-1334. http://dx.doi.org/10.1016/j. foodchem.2010.07.076.

Jiménez-Colmenero, F., Herrero, A., Pintado, T., Solas, M. T., \& RuizCapillas, C. (2010). Influence of emulsified olive oil stabilizing system used for pork backfat replacement in frankfurter. Food Research International, 43(8), 2068-2076. http://dx.doi.org/10.1016/j. foodres.2010.06.010.

Kasprzyk, A., Tyra, M., \& Babicz, M. (2015). Fatty acid profile of pork from a local and a commercial breed. Archiv fur Tierzucht, 58(2), 379-385. http://dx.doi.org/10.5194/aab-58-379-2015.

Khoddami, A., Ariffin, A. A., Bakar, J., \& Ghazali, H. M. (2009). Fatty Acid Profie of Oil Extracted from Fish Waste (Head, Intestine and Liver) (Sardine lemuru). World Applied Sciences Journal, 7(1), 127-131.

Kilic, B., \& Richards, M. P. (2003). Lipid oxidation in poultry doner kebab: pro-oxidative and anti-oxidative factors. Journal of Food Science, 68(2), 886-889. http://dx.doi.org/10.1111/j.1365-2621.2003. tb05732.x.

Kılıç, B., Şimşek, A., Claus, J. R., Karaca, E., \& Bilecen, D. (2018). Improving lipid oxidation inhibition in cooked beef hamburger patties during refrigerated storage with encapsulated polyphosphate incorporation. Lebensmittel-Wissenschaft + Technologie, 92, 290-296. http://dx.doi.org/10.1016/j.lwt.2018.02.037.

La Bella, S., Tuttolomondo, T., Lazzeri, L., Matteo, R., Leto, C., \& Licata, M. (2019). An agronomic evaluation of new safflower (Carthamus tinctorius L.) germplasm for seed and oil yields under Mediterranean climate conditions. Agronomy (Basel), 9(8), 468. http://dx.doi. org/10.3390/agronomy 9080468 .

Lee, H. J., Jung, E. H., Lee, S. H., Kim, J. H., Lee, J. J., \& Choi, Y. I. (2015). Effect of replacing pork fat with vegetable oils on quality properties of emulsion-type pork sausages. Korean Journal for Food Science of Animal Resources, 35(1), 130-136. http://dx.doi.org/10.5851/ kosfa.2015.35.1.130. PMid:26761810.
Lemon, D. W. (1975). An improved TBA test for rancidity (No. 51, New Series Circular). Halifax, Nova Scotia: Halifax Laboratory.

López-López, I., Cofrades, S., \& Jiménez-Colmenero, F. (2009). Low-fat frankfurters enriched with n_3 PUFA and edible seaweed: Effects of olive oil and chilled storage on physicochemical, sensory and microbial characteristics. Meat Science, 83(1), 148-154. http://dx.doi. org/10.1016/j.meatsci.2009.04.014. PMid:20416775.

Lorenzo, J. M., Munekata, P. E. S., Pateiro, M., Campagnol, P. C. B., \& Domínguez, R. (2016). Healthy Spanish salchichón enriched with encapsulated $\mathrm{n}-3$ long chain fatty acids in konjac glucomannan matrix. Food Research International, 89(Pt 1), 289-295. http://dx.doi. org/10.1016/j.foodres.2016.08.012. PMid:28460917.

Lorenzo, J. M., Pateiro, M., Fontán, M. C. G., \& Carballo, J. (2014). Effect of fat content on physical, microbial, lipid and protein changes during chill storage of foal liver pâté. Food Chemistry, 155, 57-63. http://dx.doi.org/10.1016/j.foodchem.2014.01.038. PMid:24594154.

Luo, M. R. (2006). Applying Colour Science in Colour Desing. Optics \& Laser Technology, 38(4-6), 392-398. http://dx.doi.org/10.1016/j. optlastec.2005.06.025.

Marangoni, A. G., Van Duynhoven, J. P., Acevedo, N. C., Nicholson, R. A., \& Patel, A. R. (2020). Advances in our understanding of the structure and functionality of edible fats and fat mimetics. Soft Matter, 16(2), 289-306. http://dx.doi.org/10.1039/C9SM01704F. PMid:31840722.

Marchetti, L., Andrés, S. C., \& Califano, A. N. (2014). Low-fat meat sausages with fish oil: Optimization of milk proteins and carrageenan contents using response surface methodology. Meat Science, 96(3), 1297-1303. http://dx.doi.org/10.1016/j.meatsci.2013.11.004. PMid:24342180.

Menegas, L. Z., Pimentel, T. C., Garcia, S., \& Prudencio, S. H. (2013). Dry-fermented chicken sausage produced with inulin and corn oil: Physicochemical, microbiological, and textural characteristics and acceptability during storage. Meat Science, 93(3), 501-506. http:// dx.doi.org/10.1016/j.meatsci.2012.11.003. PMid:23273457.

Muguerza, E., Fista, G., Ansorena, D., Astiasaran, I., \& Bloukas, J. G. (2002). Effect of fat level and partial replacement of pork backfat with olive oil on processing and quality characteristics of fermented sausages. Meat Science, 61(4), 397-404. http://dx.doi.org/10.1016/ S0309-1740(01)00210-8. PMid:22061068.

Novakovic, S., Djekic, I., Klaus, A., Vunduk, J., Djordjevic, V., Tomović, V., Šojic, B., Kocic-Tanackov, S., Lorenzo, J. M., Barba, F. J., \& Tomasevic, I. (2019). The Effect of Cantharellus Cibarius Addition on Quality Characteristics of Frankfurter during Refrigerated Storage. Foods, 8(12), 635. http://dx.doi.org/10.3390/foods8120635. PMid:31816984.

Ospina-E, J. C., Rojano, B., Ochoa, O., Pérez-Álvarez, J. A., \& FernándezLópez, J. (2015). Development of frankfurter-type sausages with healthy lipid formulation and their nutritional, sensory and stability properties. European Journal of Lipid Science and Technology, 117(1), 122-131. http://dx.doi.org/10.1002/ejlt.201400157.

Özvural, E. B., \& Vural, H. (2008). Utilization of interesterified oil blends in the production of frankfurters. Meat Science, 78(3), 211-216.

Paglarini, C. S., Furtado, G. F., Biachi, J. P., Vidal, V. A. S., Martini, S., Forte, M. B. S., Cunha, R. L., \& Pollonio, M. A. R. (2018). Functional emulsion gels with potential application in meat products. Journal of Food Engineering, 222, 29-37. http://dx.doi.org/10.1016/j. jfoodeng.2017.10.026.

Paglarini, C. S., Furtado, G. F., Honório, A. R., Mokarzel, L., Vidal, V. A. S., Ribeiro, A. P. B., Cunha, R. L., \& Pollonio, M. A. R. (2019). Functional emulsion gels as pork back fat replacers in Bologna sausage. Food Structure, 20, 100105. http://dx.doi.org/10.1016/j. foostr.2019.100105. 
Paglarini, C. S., Vidal, V. A. S., Santos, M., Coimbra, L. O., Esmerino, E. A., Cruz, A. G., \& Pollonio, M. A. R. (2020). Using dynamic sensory techniques to determine drivers of liking in sodium and fat-reduced Bologna sausage containing functional emulsion gels. Food Research International, 132, 109066. http://dx.doi.org/10.1016/j. foodres.2020.109066. PMid:32331676.

Pappa, I. C., Bloukas, J. G., \& Arvanitoyannis, I. S. (2000). Optimization of salt, olive oil and pectin level for low-fat frankfurters produced by replacing pork backfat with olive oil. Meat Science, 56(1), 81-88. http://dx.doi.org/10.1016/S0309-1740(00)00024-3. PMid:22061775.

Pereira, J., Brohi, S. A., Malairaj, S., Zhang, W., \& Zhou, G. H. (2020). Quality of fat-reduced frankfurter formulated with unripe banana by-products and pre-emulsified sunflower oil. International Journal of Food Properties, 23(1), 420-433. http://dx.doi.org/10.1080/1094 2912.2020.1733014.

Reddy, K. J., Jayathilakan, K., \& Pandey, M. C. (2015). Olive oil as functional component in meat and meat products: a review. Journal of Food Science and Technology, 52(11), 6870-6878. http://dx.doi. org/10.1007/s13197-015-1852-x.

Rodríguez-Carpena, J. G., Morcuende, D., \& Estévez, M. (2012). Avocado, sunflower and olive oils as replacers of pork back-fat in burger patties: Effect on lipid composition, oxidative stability and quality traits. Meat Science, 90(1), 106-115. http://dx.doi.org/10.1016/j. meatsci.2011.06.007. PMid:21703779.

Selani, M. M., Shirado, G. A. N., Margiotta, G. B., Rasera, M. L., Marabesi, A. C., Piedade, S. M. S., Contreras-Castillo, C. J., \& CanniattiBrazaca, S. G. (2016). Pineapple by-product and canola oil as partial fat replacers in low-fat beef burger: Effects on oxidative stability, cholesterol content and fatty acid profile. Meat Science, 115, 9-15. http://dx.doi.org/10.1016/j.meatsci.2016.01.002. PMid:26775152.

Sisik, S., Kaban, G., Karaoglu, M. M., \& Kaya, M. (2012). Effects of corn oil and broccoli on instrumental texture and color properties of bologna-type sausage. International Journal of Food Properties, 15(5), 1161-1169. http://dx.doi.org/10.1080/10942912.2010.517339.

Tahmasebi, M., Labbafi, M., Emam-Djomeh, Z., \& Yarmand, M. S. (2016). Manufacturing the novel sausages with reduced quantity of meat and fat: the product development, formulation optimization, emulsion stability and textural characterization. Lebensmittel-Wissenschaft + Technologie, 68, 76-84. http://dx.doi.org/10.1016/j.lwt.2015.12.011.
Tan, S. S., Aminah, A., Zhang, X. G., \& Abdul, S. B. (2006). Optimizing palm oil and palm stearin utilization for sensory and textural properties of chicken frankfurters. Meat Science, 72(3), 387-397. http://dx.doi.org/10.1016/j.meatsci.2005.07.012. PMid:22061722.

Turkish Standards Institute - TSE. (2016). TS 980 sausage (pp. 11). Ankara: Turkish Standards Institute.

Vargas-Ramella, M., Pateiro, M., Barba, F. J., Franco, D., Campagnol, P. C. B., Munekata, P. E., Tomasevic, I., Domínguez, R., \& Lorenzo, J. M. (2020). Microencapsulation of healthier oils to enhance the physicochemical and nutritional properties of deer pâté. LebensmittelWissenschaft + Technologie, 125, 109223. http://dx.doi.org/10.1016/j. lwt.2020.109223.

Vural, H. (2003). Effect of replacing beef fat and tail fat with interesterified plant oil on quality characteristics of Turkish semi-dry fermented sausages. European Food Research and Technology, 217(2), 100-103. http://dx.doi.org/10.1007/s00217-003-0727-y.

Wang, X., Xie, Y., Li, X., Liu, Y., \& Yan, W. (2018). Effects of partial replacement of pork back fat by a camellia oil gel on certain quality characteristics of a cooked style Harbin sausage. Meat Science, 146, 154-159. http://dx.doi.org/10.1016/j.meatsci.2018.08.011. PMid:30149279.

Yıldız-Turp, G., \& Serdaroğlu, M. (2008). Effect of replacing beef fat with hazelnut oil on quality characteristics of sucuk - a Turkish fermented sausage. Meat Science, 78(4), 447-454. http://dx.doi. org/10.1016/j.meatsci.2007.07.013. PMid:22062464.

Yılmaz, I., Şimşek, O., \& Işıklı, M. (2002). Fatty acid composition and quality characteristics of low-fat cooked sausages made with beef and chicken meat, tomato juice and sunflower oil. Meat Science, 62(2), 253-258. http://dx.doi.org/10.1016/S0309-1740(01)00255-8. PMid:22061419.

Zhuang, X., Han, M., Kang, Z., Wang, K., Bai, Y., Xu, X., \& Zhou, G. (2016). Effects of the sugarcane dietary fiber and pre-emulsified sesame oil on low-fat meat batter physicochemical property, texture and microstructure. Meat Science, 113, 107-115. http://dx.doi. org/10.1016/j.meatsci.2015.11.007. PMid:26641280.

Zlatko, P., Aleksandra, S.N., Katerina, B., Lea, G., Tomaz, P., Božidar, S.L., \& Herbert, O. (2009). Effect of vegetable fats and oils on sensory characteristics of processed chichen frankfurter- style sausages. Tehnologija Mes, 50(5-6), 351-357. 